\title{
Stakeholder identification methods used in private organisations' projects in Nigeria
}

\author{
Nathaniel Ayinde Olatunde \\ Quantity Surveying Department, Federal University Oye-Ekiti, Oye, Nigeria \\ Imoleayo Abraham Awodele \\ Quantity Surveying Department, Durban University of Technology, \\ Durban, South Africa, and \\ Henry Agboola Odeyinka \\ Quantity Surveying, Obafemi Awolowo University, Ile-Ife, Nigeria
}

\begin{abstract}
Purpose - The purpose of the study is to examine the stakeholder identification (SI) methods used in building projects procured by private corporate organisations in Southwestern Nigeria to draw a correlation between methods used for SI and project performance in the study area, thereby enhancing project performance.

Design/methodology/approach - The study used a census survey to purposively select 30 projects managers (who indicated from a first-stage questionnaire) that they have participated in structured stakeholder management (SM) from a list of 106 project managers and client representatives who have been involved in SM of building projects procured by private corporate organisations between 2008 and 2017 in the study area. A second-stage questionnaire was designed to elicit information from the respondents. The quantitative data that were collected were analysed using mean score (MS) analysis and Analysis of variance (ANOVA).

Findings - The study found that brainstorming in group meetings (MS $=4.33$ ), interviews with the expert $(\mathrm{MS}=3.20)$ and identification by other stakeholders (MS $=3.00$ ) are the most frequently used SI methods in the study area. It was also found that the use of a questionnaire ( $M S=0.87$ ), Delphi method ( $M S=0.80)$ and public hearing (MS = 0.57) was rare for SI in the study area. A further result showed that there was no significant difference in the opinion of project managers on $85 \%$ of methods used for SI in the study area irrespective of the procurement method employed.

Practical implications - The study examined the methods project managers used for SI on building projects procured by private corporate organisations to advocate for more robust and all-inclusive SI methods.

Originality/value - The study empirically examined methods used for SI and correlated them to project performance.
\end{abstract}

Keywords Building projects, Private, Corporate organisations and stakeholder identification

Paper type Research paper

\section{Introduction}

Generically, a stakeholder is defined as an individual, coalition of individuals or firm that participates in a particular organisation, project, system, etc., mostly because they have invested money in such an organisation (Hornby, 2014). Several strategic management pieces of research have grouped the various definitions of a stakeholder into descriptive/analytical and normative approaches (Friedman and Miles, 2006). In a widely used analytical definition

C Nathaniel Ayinde Olatunde, Imoleayo Abraham Awodele and Henry Agboola Odeyinka. Published in Frontiers in Engineering and Built Environment. Published by Emerald Publishing Limited. This article is published under the Creative Commons Attribution (CC BY 4.0) licence. Anyone may reproduce, distribute, translate and create derivative works of this article (for both commercial and non-commercial purposes), subject to full attribution to the original publication and authors. The full terms of this licence may be seen at http://creativecommons.org/licences/by/4.0/legalcode

Identifying stakeholders

Received 14 May 2021

Revised 23 June 2021 9 September 2021 
FEBE 1,2 by Freeman (1984), a stakeholder is defined as anyone who may be affected or who affects the realisation of the objectives of an organisation. According to Feige et al. (2011), the working definition for stakeholders in strategic management is any entity, group or individual that may be affected by or that affects the activities around, and the realisation of a defined issue, past, present, and future.

In the word of McElroy and Mills (2003), a construction project stakeholder is an individual or coalition of individuals who possess a vested interest in the successful implementation of a project. Here, the definition tries to bring together, into a single project, the internal and external stakeholders. Oftentimes, while internal stakeholders are interested in the successful completion of the project, on the contrary, the fact that the project operates within their environment is the only thing that interests the external stakeholders. According to Bourne (2009), stakeholders are those individuals or groups that are usually either affected by or can influence the organisation's success or failure as it relates to the organisation's activities. The foregoing definitions reaffirm the stakeholders' power in determining the successful completion of a project or otherwise. This is because the stakeholders are capable of influencing the success or failure of a particular project.

From these definitions, it is evident that stakeholders cover a wide range of individuals and groups, who are directly or indirectly involved in projects and have the ability to influence, determine, or ensure the success or failure of such projects, using their influence. In a typical construction project, while many stakeholders have contractual rights, there are those with a vested interest, while others are placed at risk. The list of stakeholders in a construction project is usually endless and may include the project team (client, contractor, architect, engineer, quantity surveyor, project manager), end-users of the project, facilities manager, shareholders, employees, subcontractors, suppliers, competitors, bankers, media, neighbours, the general public, various levels of government and its agent, and the unborn generation (Smith and Love, 2004; Yang et al., 2011). Eyiah-Botwe (2015) posited that clients, site personnel, communities, project managers, subcontractors, professional bodies, local governments, contractors, media, politicians, political parties and members of parliament are major construction stakeholders. Olatunde (2019), identified stakeholders on private corporate organisation building projects to include clients, project contractors, project managers, project architects, project civil/structural engineers, project service engineers, project quantity surveyors, project subcontractors, project material suppliers, facility management teams, project land surveyors, local residents, local landowners, environmental miscreants (omo onile), company shareholders, customers, company staff, financial institutions and contractor workmen. Others are the town-planning authority, conservationists, environmentalists, environmental impact assessors, the media, state government, passersby, civil organisations, regulatory agencies, local government authorities and federal government.

With these numerous stakeholders on construction projects, there is always a high possibility for conflict of interests among them (Lynch, 2006), and if an organisation focuses on one stakeholder alone or a group of stakeholders, the interest of the others may be neglected (Doyle and Stern, 2006). Therefore, each organisation must effectively, extensively, and completely identify and engage with all its stakeholders. Consequent on this, Buertey et al. (2016) opined that stakeholders should be differentiated into stake watchers and stake keepers. The study opined that stakeholders are individuals with a visible and significant stake in a corporation. Stake watchers, however, may not necessarily have a stake of their own; they rather oversee the stake of actual stakeholders. For instance, stake watchers are unions and community pressure groups. On the other hand, stake keepers are the independent regulators who have no stake in the firm but can impact and exercise control. Examples are standard and compliance organisations (Giordano et al., 2007). Phantom stakeholders are people who are 
subject to, part of or impacted by the project, yet have not formally been identified by the project manager or project team as stakeholders (PMBOK, 2013).

Research has identified the underestimation of stakeholders' influence on construction projects as a major factor responsible for project delay and increase in construction cost (Yang et al., 2009). This underestimation and poor stakeholder management usually begin with incomplete stakeholder identification. For instance, underestimation of the influence of stakeholders was responsible for twelve months of delay in the commencement of construction work on the sea-crossing bridge project designed to connect Zhuhai in mainland China to Hong Kong and Macao due to a legal dispute regarding the ecological impact of the bridge The cost of the delay and legal tussle was valued in millions of dollars (Macau Daily Times, 2011; Mok et al., 2015).

The primary task for a project manager is that he needs to identify, consider and satisfy a variety of stakeholders (Aaltonen, 2010); however, the method and strategies of stakeholder identification (SI) remained unstructured which makes the result inadequate. For instance, Aapaoja and Haapasalo (2014) opined that the Finnish construction industry has strictly followed the national building code in identification and management of stakeholders. This approach presents stakeholders as one ridged group, as this simple management approach is not effective in the complex and dynamic project environment of the twenty-first century. The study by Dietrich et al. (2010) argued that there are no systematic approaches or methods for SI and management in the construction industry which is causing a major problem of project performance, like time and cost overruns on several projects (Olatunde and Alao, 2017). Aaltonen et al. (2008) posited that stakeholder analysis and the identification aims to facilitate the understanding of how to manage stakeholders in invariably changing and unpredictable environments. Previous studies on stakeholder management on construction projects have mentioned the various methods of SI (Chevalier and Buckles, 2008; Jepsen and Eskerod, 2009; Karlsen, 2002); however, none of the studies have empirically tested the methods used by project managers to identify stakeholders in their projects; neither do they differentiate the opinions of project managers on SI methods when different procurement methods are used (Von and Achterkamp, 2006; Olatunde, 2019; Olatunde and Odeyinka, 2021a), hence the gap this study intended to fill. Although Olatunde and Odeyinka (2021a) while assessing the extent of stakeholder management practices in building projects procured by private corporate organisations in Nigeria mentioned SI as an important step in the structured SM process, the study found that respondents placed the highest premium on SI and the lowest premium on developing implementation strategies and stakeholder classification. In another study, Olatunde and Odeyinka (2021b) appraised factors influencing stakeholder management in building projects procured by private corporate organisations and found that the most important factors influencing SM comprise maintaining good relationships with stakeholders, addressing stakeholders' concerns, and needs and avenue for communicating project impacts. Yang et al. (2009) did an overview of previous studies in stakeholder management and its implications for the construction industry and found that very few methods and tools are available to identify all stakeholders and their interests in construction projects. The study further asserted that project managers need to know particular methods to identify stakeholders and their interests in practice and suggested that the social network theory provides some ideas about the method to identify stakeholders. From the foregoing, none of the studies has empirically examined SI methods used in building projects procured by private corporate organisations. As such the gap still exists. The need to undertake the study on private corporate organisations' projects is glaring, not only because majority of studies on SM were largely on public projects but also because projects of private organisations need much improvement, as well as because private organisations cannot afford the inefficiency associated with public organisation projects
Identifying stakeholders 
FEBE 1,2

(Olatunde and Alao, 2017). Hence, there is need for stricter management of resources to enhance project performance.

The objective of the study was to appraise SI methods used in building projects procured by private corporate organisations in Southwestern Nigeria. To further examine this objective in a quantitative term, a hypothesis was formulated to investigate whether a significant difference exists in the opinion of project managers on SI methods used in building projects procured by private corporate organisations in the study area when the traditional, management contracting and design and build procurement methods are used for the projects; this was with a few to draw a correlation between methods used for SI and project performance in the study area.

\section{Literature review}

The majority of the various proponents of different models for structured SM on construction projects have asserted that SI is the first step in the SM process (Aaltonen et al., 2008; Olatunde, 2019). For instance, Lock (2007) opined that stakeholder management should consist of methodical identification of stakeholders, analysis, planning actions, communication and negotiation targeted at influencing project stakeholders. Karlsen (2002) suggested a six-step model for SM including initial planning, identification, analysis, communication, action and follow-up. Olatunde (2019) adapted the six-step model suggested by Karlsen (2002) as the most comprehensive SM process and proposed a model that entails stakeholder identification, classification, analysis, engagement, developing an implementation strategy, and follow-up action on strategy. This stage focuses on the identification of stakeholders. The management team needs to identify both active stakeholders and potential stakeholders on the project. According to Gil-Lafuente and Paula (2013), the list of stakeholders for any organisation is not static, because project stakeholders change depending on the issue in question. Mitchell et al. (1997) proposed a three-core criteria process model for SI which are based on the relationship attributes of power, legitimacy and urgency.

The type of relationship that exists between stakeholders and the organisation is another method of identifying stakeholders (Gil-Lafuente and Paula, 2013). This could be by responsibility, influence, proximity, dependency or representation. Karlsen (2002) opined that some of the techniques that can be used for SI include interviews with experts, brainstorming in group meetings, the use of checklists and value management workshops. The study by Awakul and Ogunlana (2002) found that identification of stakeholders and their interests are usually conducted through deskwork and questionnaires. In the words of Reed et al. (2009) stakeholders' identification is usually an iterative process during which additional stakeholders are added as the analysis continues. The study further submits that the tools used for SI are snowball sampling, semi-structured interviews, expert opinion, focus groups or a combination of these.

Chevalier and Buckles (2008) identified a range of other means to identify stakeholders; these include identification by experts or other stakeholders, by self-selection (in response to advertisements), through written records, through oral or written accounts of major events, or using a checklist of likely stakeholder categories. Awakul and Ogunlana (2002) suggested five stakeholder groups in construction projects: the groups affected by the project, the project participants, Non Government Organization (NGO) and interested organisations, academics and experts, and the local government officials. Olander and Landin (2008), however, identified six major groups of construction stakeholders, which are project owners, government agencies, the public, local trade, employees and suppliers, and the media. One other major way of SI is through stakeholder characterisation (Jepsen and Eskerod, 2009). SI is an all-important step in SM, as virtually all studies (Aaltonen et al., 2008; Jepsen and Eskerod, 2009) in this area alluded to this and included the step in their model. Table 1 summarises literature classification on methods of SI. 


\begin{tabular}{|c|c|c|c|}
\hline $\mathrm{S} / \mathrm{N}$ & Stakeholder identification method & Authors & ying \\
\hline 1 & Relationship attributes & Mitchell et al. (1997), Gil-Lafuente and Paula (2013) & \\
\hline 2 & Interviews with experts & $\begin{array}{l}\text { Karlsen (2002), Reed et al. (2009), Chevalier and Buckles } \\
\text { (2008) }\end{array}$ & \\
\hline 3 & Brainstorming in group meetings & Karlsen (2002) & \\
\hline 4 & Identification by other stakeholders & Chevalier and Buckles (2008) & \\
\hline 5 & Through written records & Chevalier and Buckles (2008) & 221 \\
\hline 6 & The use of checklists & Karlsen (2002), Chevalier and Buckles (2008) & \\
\hline 7 & Through value management workshops & Karlsen (2002) & \\
\hline 8 & Through deskwork and a questionnaire & Awakul and Ogunlana (2002) & \\
\hline 9 & Snowball sampling & Reed et al. (2009) & \\
\hline 10 & $\begin{array}{l}\text { Through oral or written accounts of major } \\
\text { events }\end{array}$ & Chevalier and Buckles (2008) & \\
\hline 11 & Self-selection (in response to advertisements) & Chevalier and Buckles (2008) & Classification \\
\hline 12 & Focus groups & Reed et al. (2009) & literature on \\
\hline 13 & Through written records & Chevalier and Buckles (2008) & stakeholder \\
\hline 14 & Through stakeholder characterisation & Jepsen and Eskerod (2009) & identification methods \\
\hline
\end{tabular}

It is glaring from the discussion above that the majority of studies in the literature on the concept of stakeholder management and specifically on SI have mentioned the different SI methods, but the majority of them did not empirically test the usability of the methods they have proposed. For instance, Yang et al. (2009) while overviewing previous studies in stakeholder management and its implications for the construction industry opined that Clarkson's (1995) study only provided a delineation theory and did not give a specific method to identify stakeholders and their interests. Aapaoja and Haapasalo (2014) produced a framework for SI and classification in construction projects. The framework provides a practical approach to stakeholder management and provides phases that are necessary to identify and classify the project stakeholders effectively from the initiation of the project to its completion. Von and Achterkamp's (2006) model suggested a four-step SI method to include defining the goal of the project, individual brainstorm (identification of the involved), group brainstorm (identification of the involved based on the role) and group brainstorm (phasing the involvement).

Karlsen's (2002) study was on project stakeholder management. The study mentioned the various processes of SM, but did not empirically examine each of the processes highlighted. Olatunde's (2019) research focused on assessment of stakeholder management in construction projects procured by private corporate organisations in Southwestern Nigeria. The study just like Karsel's (2002), though highlighted the various SM processes in its framework, did not focus on SI methods. Olander and Landin's (2008) research focused on a comparative study of factors affecting the external stakeholder management process and not on SI. It is obvious from the literature classification of the empirical study above that previous studies have not focussed their analysis on empirical examination of methods used for stakeholder identification; hence, the gap in the study still exists in the literature.

\section{Research methodology}

The objective reported in this study was to appraise the methods used for SI of building projects procured by private corporate organisations in Southwestern Nigeria as part of a larger study on "assessment of stakeholder management in construction projects procured by private corporate organisations in Southwestern Nigeria". To achieve this, a total enumeration of 30 project managers was selected from a list of 106 project managers and 
FEBE 1,2 client representatives who have been involved in stakeholder management of building projects procured by private corporate organisations in Southwest Nigeria between 2008 and 2017.

The 30 project managers were selected based on their response in a first-stage questionnaire that they have been involved in the structured SM process on building projects procured by private corporate organisations in the study area. The need to select project managers for the survey was to ensure reliability and ensure that the right population with the required information were contacted, since the literature has confirmed that SM on a construction project is the exclusive duty of the project manager (Bourne and Walker, 2006; Mok et al., 2015). The study considered the 30 respondents adequate for the study due to the assertion of Oke and Ogunsemi (2009) that the result of a survey could be considered as biased and of little significance if the return rate was lower than $20-30 \%$ of the total population. In this case, the 30 respondents represent $41 \%$, hence its adequacy. The ten-year period was selected as it represents a period of economic instability in the country (Agri et al., 2017). As such, it is thought that opinions expressed on projects executed within the period would be about the same.

A second-stage questionnaire was designed to gather information regarding the objective of the study and administered to the project managers. The need to use a second-stage questionnaire to collect data for this study rather than an interview was justified by the quantitative nature of data required. Another motivation for the use of a second-stage questionnaire rather than an interview was to ease data analysis because at the heart of the research is data analysis. The respondents were asked questions relating to their background such as their academic qualification, professional inclination, designation, number of projects executed, etc. The necessity for this background information was to ensure they were qualified to supply the information required of them. Respondents were further asked to rate the extent to which they have used the identified SI methods from the literature on building projects procured by private corporate organisations they have been involved in the study area on an interval scale 1 to 5 ; where 1 - very low extent, 2 - low extent, 3 - moderate extent, 4 - high extent and 5 - very high extent. Responses of respondents for data collection were discriminated along the procurement route (traditional, contract management, and design and build), and analysis of their responses was carried out with the use of mean score (MS) analysis and ANOVA. The choice of MS analysis was considered appropriate for the study because the mean ranking of the respondents was required to take a statistical position. Similar empirical research studies on the concept of SM (Aaltonen, 2011; Yang et al., 2011; Yang and Shen, 2015) have used the same methodology for data collection. The Cronbach's alpha measure of reliability/internal consistency was used to measure the reliability of the data collected. The Cronbach's alpha coefficient was 0.82 . Since the figure is above 0.7 (DeVellis, 2003), it suggests that the data collected are adequate and the responses were reliable.

\section{Research hypothesis}

The objective of the study was to appraise the methods used for SI in building projects procured by private corporate organisations in Southwestern Nigeria. One null hypothesis was formulated to further examine the objective of this research in quantitative terms.

H1. There is no significant difference in the methods of SI in the study area irrespective of procurement methods.

ANOVA was used to examine if a statistically significant difference exists in the opinion of the respondents on methods of SI when traditional, contract management and, design and build procurement methods were employed on the projects. Precious studies on the concept of 
stakeholder management have used that same methodology (Olatunde and Odeyinka (2021a, b).
Identifying stakeholders

\section{Results}

Characteristics of the respondents to the questionnaire

Table 2 shows the characteristics of the respondents sampled for the study. The results indicated that all the respondents had the required academic and professional qualifications to supply the information required of them. Results showed that the majority $(73.33 \%)$ of them were Master of Science/Technology degree holders, and all of them $(100 \%)$ were at least associate (corporate) members of their respective professional associations.

Concerning work experience, the table shows that respondents have between 10 and 33 years of work experience in the Nigerian construction industry, and could be said to have gathered sufficient experience in the industry. Similarly, each of them has executed at least 15 construction projects. This background information suffices to authenticate the information supplied by the respondents.

Table 3 presents a summary of the number of respondents based on their primary professions or the nature of work they undertake. Almost half of them $(43.33 \%)$ were quantity surveyors/project managers, $40.00 \%$ were architect/project managers and only $16.67 \%$ were practicing primarily as project managers. These figures showed the respondents cut across the targeted population for the study. Hence, the data supplied could be relied on.

\section{Methods used in stakeholder identification}

Table 4 shows the responses of the respondents on methods used for SI in the study area. Brainstorming in group meetings (MS = 4.33) was ranked 1st, as the most frequently used method of stakeholder identification. Other methods used were, interviews with the expert $(\mathrm{MS}=3.20$ ) ranked 2 nd and identification by other stakeholders ( $\mathrm{MS}=3.00)$. In contrast, use of a questionnaire $(\mathrm{MS}=0.87$ ) ranked 11 th, the Delphi method $(\mathrm{MS}=0.80)$ ranked 12 th and public hearing ( $\mathrm{MS}=0.57$ ) ranked 13th, respectively, were the least used methods for SI in the study area.

The result of the ANOVA shows that the procurement types used in the projects only have a significant statistical difference on minority ("written records or census data" and "selfselection in response to an advertisement or announcement") of the methods used for stakeholder identification. This result implies that project managers ranked $84.62 \%$ of the methods used for SI the same way, while their opinion was statistically different on only $15.38 \%$ of the methods. The difference in perception on $15.38 \%$ of the methods used for SI could be attributed to the fact that the methods on which the project managers have dissecting opinions were not the major methods used for SI in the study area, as they were ranked 7 th and 9 th position by the respondents.

\section{Discussion}

The first result that brainstorming in a group meeting is the commonest method of SI in the study area implied that project managers often identified stakeholders on their projects during design team meetings (as evident from the MS rating). The margin of difference between "brainstorming in a group meeting" and "interview with experts" as a method of identifying stakeholders in the study area is wide as such the project managers preferred the use of brainstorming in group meetings to other methods without considering the consequences of the omission of key stakeholders. One major inference that could be drawn from the use of brainstorming in a group meeting to identify stakeholders in construction projects in the study area is that project managers do not endeavour to expend additional resources that may be 


\section{FEBE}

1,2

\begin{tabular}{|c|c|c|c|c|c|c|}
\hline $\mathrm{S} / \mathrm{n}$ & $\begin{array}{l}\text { Profession of } \\
\text { interviewee }\end{array}$ & $\begin{array}{l}\text { Years of } \\
\text { experience }\end{array}$ & $\begin{array}{l}\text { Highest } \\
\text { academic } \\
\text { qualification }\end{array}$ & $\begin{array}{l}\text { Membership of } \\
\text { professional } \\
\text { bodies }\end{array}$ & Designation & $\begin{array}{l}\text { No. of } \\
\text { projects } \\
\text { executed }\end{array}$ \\
\hline 1 & Architect/PM & 13 & MSc & NIA/associate & $\begin{array}{l}\text { Senior } \\
\text { architect }\end{array}$ & $>15$ \\
\hline 2 & $\mathrm{QS} / \mathrm{PM}$ & 7 & HND & NIQS/associate & Project QS & $>30$ \\
\hline 3 & $\mathrm{QS} / \mathrm{PM}$ & 20 & PGD & NIQS/associate & $\begin{array}{l}\text { Associate } \\
\text { partner }\end{array}$ & $>20$ \\
\hline 4 & PM & 15 & MSc & $\begin{array}{l}\text { PMI/RICS/ } \\
\text { Associate }\end{array}$ & $\begin{array}{l}\text { Principal } \\
\text { partner }\end{array}$ & $>15$ \\
\hline 5 & $\mathrm{QS} / \mathrm{PM}$ & 20 & HND & NIQS/associate & $\begin{array}{l}\text { Associate } \\
\text { partner }\end{array}$ & $>10$ \\
\hline 6 & Architect/PM & 33 & MSc & NIA/associate & $\begin{array}{l}\text { Principal } \\
\text { partner }\end{array}$ & $>25$ \\
\hline 7 & PM & 32 & MSc & $\begin{array}{l}\text { RICS/NIQS/ } \\
\text { fellow }\end{array}$ & $\begin{array}{l}\text { Group- } \\
\text { managing } \\
\text { partner }\end{array}$ & $>20$ \\
\hline 8 & Architect/PM & 21 & MTech & NIA/associate & $\begin{array}{l}\text { Principal } \\
\text { partner }\end{array}$ & $>10$ \\
\hline 9 & PM & 20 & MSc & PMI/associate & $\begin{array}{l}\text { Principal } \\
\text { partner }\end{array}$ & $>30$ \\
\hline 10 & $\mathrm{QS} / \mathrm{PM}$ & 10 & MSc & NIQS/associate & $\begin{array}{l}\text { Project } \\
\text { director }\end{array}$ & $>15$ \\
\hline 11 & $\mathrm{QS} / \mathrm{PM}$ & 16 & MSc & $\begin{array}{l}\text { RICS/NIQS/ } \\
\text { associate }\end{array}$ & Chief QS & $>10$ \\
\hline 12 & $\mathrm{QS} / \mathrm{PM}$ & 10 & MTech & NIQS/associate & $\begin{array}{l}\text { Principal } \\
\text { partner }\end{array}$ & $>15$ \\
\hline 13 & Architect/PM & 10 & MSc & NIA/associate & $\begin{array}{l}\text { Project } \\
\text { architect }\end{array}$ & $>25$ \\
\hline 14 & Architect/PM & 8 & MTech & NIA/associate & $\begin{array}{l}\text { Project } \\
\text { architect }\end{array}$ & $>10$ \\
\hline 15 & Architect/PM & 20 & MTech & NIA/fellow & $\begin{array}{l}\text { Principal } \\
\text { partner }\end{array}$ & $>30$ \\
\hline 16 & $\mathrm{QS} / \mathrm{PM}$ & 16 & PGD & NIQS/associate & Chief QS & $>20$ \\
\hline 17 & PM & 9 & MSc & $\begin{array}{l}\text { PMI/NIQS/ } \\
\text { associate }\end{array}$ & $\begin{array}{l}\text { Senior project } \\
\text { manager }\end{array}$ & $>25$ \\
\hline 18 & Architect/PM & 19 & MArch & $\begin{array}{l}\text { NIA/PMI/ } \\
\text { associate }\end{array}$ & $\begin{array}{l}\text { Project } \\
\text { architect }\end{array}$ & $>20$ \\
\hline 19 & Architect/PM & 12 & MTech & NIA/associate & $\begin{array}{l}\text { Associate } \\
\text { partner }\end{array}$ & $>15$ \\
\hline 20 & Architect/PM & 17 & MSc & $\begin{array}{l}\mathrm{NIA} / \mathrm{PMI} / \\
\text { associate }\end{array}$ & $\begin{array}{l}\text { Project } \\
\text { coordinator }\end{array}$ & $>10$ \\
\hline 21 & $\mathrm{PM} / \mathrm{QS}$ & 14 & PGD & NIQS/associate & Project QS & $>25$ \\
\hline 22 & Architect/PM & 25 & MArch & NIA/fellow & $\begin{array}{l}\text { Principal } \\
\text { partner }\end{array}$ & $>20$ \\
\hline 23 & $\mathrm{PM} / \mathrm{QS}$ & 9 & $\mathrm{BSc}$ & $\begin{array}{l}\text { PMI/RICS/ } \\
\text { associate }\end{array}$ & $\begin{array}{l}\text { Associate } \\
\text { partner }\end{array}$ & $>15$ \\
\hline 24 & $\mathrm{QS} / \mathrm{PM}$ & 15 & HND & $\begin{array}{l}\text { NIQS/PMI/ } \\
\text { associate }\end{array}$ & $\begin{array}{l}\text { Associate } \\
\text { partner }\end{array}$ & $>20$ \\
\hline 25 & Architect/PM & 33 & MSc & NIA/PMI/fellow & $\begin{array}{l}\text { Principal } \\
\text { partner }\end{array}$ & $>15$ \\
\hline 26 & $\mathrm{QS} / \mathrm{PM}$ & 30 & MSc & $\begin{array}{l}\text { RICS/NIQS/ } \\
\text { fellow }\end{array}$ & $\begin{array}{l}\text { Group } \\
\text { managing } \\
\text { partner }\end{array}$ & $>25$ \\
\hline
\end{tabular}

Table 2.

Profile of respondents 


\begin{tabular}{|c|c|c|c|c|c|c|c|}
\hline $\mathrm{S} / \mathrm{n}$ & $\begin{array}{l}\text { Profession of } \\
\text { interviewee }\end{array}$ & $\begin{array}{c}\text { Years of } \\
\text { experience }\end{array}$ & $\begin{array}{l}\text { Highest } \\
\text { academic } \\
\text { qualification }\end{array}$ & $\begin{array}{l}\text { Membership of } \\
\text { professional } \\
\text { bodies }\end{array}$ & Designation & $\begin{array}{l}\text { No. of } \\
\text { projects } \\
\text { executed }\end{array}$ & $\begin{array}{l}\text { Identifying } \\
\text { stakeholders }\end{array}$ \\
\hline 27 & Architect/PM & 21 & MTech & $\begin{array}{l}\text { NIA/PMI/ } \\
\text { associate }\end{array}$ & $\begin{array}{l}\text { Principal } \\
\text { partner }\end{array}$ & $>10$ & \\
\hline 28 & PM & 20 & $\mathrm{MSc}$ & PMI/associate & $\begin{array}{l}\text { Principal } \\
\text { partner }\end{array}$ & $>20$ & 225 \\
\hline 29 & $\mathrm{QS} / \mathrm{PM}$ & 10 & PGD & NIQS/associate & $\begin{array}{l}\text { Project } \\
\text { director }\end{array}$ & $>15$ & \\
\hline 30 & $\mathrm{QS} / \mathrm{PM}$ & 16 & $\mathrm{MSc}$ & $\begin{array}{l}\text { RICS/NIQS/ } \\
\text { associate }\end{array}$ & Chief QS & $>15$ & \\
\hline
\end{tabular}

Note(s): $\mathrm{QS}=$ Quantity Surveyor, $\mathrm{PM}=$ Project manager, $\mathrm{MSc}=$ Master of Science, $\mathrm{HND}=$ Higher National Diploma, $\mathrm{PGD}=$ Post Graduate Diploma, MTech = Master of Technology, MArch = Master of Architecture, BSc $=$ Bachelor of Science, NIA = Nigerian institute of Architects, NIQS $=$ Nigerian institute of Quantity Surveyors, PMI = Project Management Institute, RICS = Royal Institute of Chartered surveyors

Table 2.

Number of interviewees and their primary professions Quantity surveying/project management Architecture/project management

Table 3. Project management Summary of the profile of respondents $13212 \quad 5 \quad \begin{array}{r}\begin{array}{r}\text { of respondents } \\ \text { (primary profession) }\end{array} \\ \hline\end{array}$

\begin{tabular}{|c|c|c|c|c|c|c|c|c|}
\hline \multirow[b]{2}{*}{$\mathrm{S} / \mathrm{N}$} & \multirow[b]{2}{*}{ Methods } & \multicolumn{2}{|c|}{ Overall } & \multirow{2}{*}{$\begin{array}{c}\text { Trad } \\
\text { MS }\end{array}$} & \multirow{2}{*}{$\begin{array}{c}\text { D\&B } \\
\text { MS }\end{array}$} & \multirow{2}{*}{$\begin{array}{l}\text { MC } \\
\text { MS }\end{array}$} & \multirow{2}{*}{$\begin{array}{l}F- \\
\text { stat }\end{array}$} & \multirow{2}{*}{$\begin{array}{c}p- \\
\text { value }\end{array}$} \\
\hline & & MS & Rank & & & & & \\
\hline 1 & Brainstorming in group meetings & 4.33 & 1 & 4.35 & 4.38 & 4.20 & 0.45 & 0.65 \\
\hline 2 & Interview with experts & 3.20 & 2 & 3.35 & 2.88 & 3.20 & 2.60 & 0.09 \\
\hline 3 & Identification by other stakeholders & 3.00 & 3 & 3.12 & 3.25 & 2.20 & 1.19 & 0.32 \\
\hline 4 & Checklist & 2.97 & 4 & 3.18 & 2.63 & 2.80 & 0.74 & 0.49 \\
\hline 5 & Focus group & 2.83 & 5 & 3.24 & 1.75 & 3.20 & 1.96 & 0.16 \\
\hline 6 & $\begin{array}{l}\text { Through oral or written account of major } \\
\text { events }\end{array}$ & 2.60 & 6 & 2.82 & 2.75 & 1.60 & 0.49 & 0.62 \\
\hline 7 & Written records or census data & 2.37 & 7 & 2.35 & 2.75 & 1.80 & 4.22 & $0.03 *$ \\
\hline 8 & Intuition & 2.20 & 8 & 1.82 & 3.38 & 1.60 & 2.95 & 0.07 \\
\hline 9 & $\begin{array}{l}\text { Self-selection in response to an advertisement } \\
\text { or announcement }\end{array}$ & 1.93 & 9 & 1.65 & 2.63 & 1.80 & 6.89 & $0.00^{*}$ \\
\hline 10 & Snowballing method & 0.93 & 10 & 0.8 & 1.13 & 0.60 & 0.42 & 0.67 \\
\hline 11 & Use of a questionnaire & 0.87 & 11 & 0.71 & 1.63 & 0.20 & 0.40 & 0.67 \\
\hline 12 & Delphi method & 0.80 & 12 & 1.06 & 0.63 & 0.20 & 0.98 & 0.39 \\
\hline 13 & Public hearing & 0.57 & 13 & 0.59 & 0.50 & 0.60 & 0.55 & 0.582 \\
\hline
\end{tabular}

Note(s): Key: * $p$ value significant at 0.05 , Trad $=$ traditional, $\mathrm{D} \& \mathrm{~B}=$ design and build, $\mathrm{MC}=$ management contracting

required to extensively and exhaustively identify all the stakeholders in a construction project. For example, it will require additional resources to organise a public hearing, but with the advantage that extensive and exhaustive SI may be guaranteed. This finding of the study could be compared to align with the assertion of Karlsen (2002) which mentioned that the techniques that can be used for SI are interviews with experts, brainstorming in group meetings and the use of checklists. Although Karlsen's (2002) assertion was not empirically tested, this could be regarded as an area of advancement by this study. 
FEBE 1,2

Another method of SI that takes dominance in the study area second to brainstorming in a group meeting is an interview with an expert. The implication of this for the study is that project managers often identify stakeholders in their projects by interviewing their colleagues as an alternative method of SI. Even though Karlsen (2002) suggested the use of an interview with experts as a method of SI, the study further emphasises that the identification procedure should take place in a group of participants with different backgrounds. In the same vein, the finding of this study could be compared to be in tandem with the position of Reed et al. (2009) which opined that the tools used for SI include snowball sampling, semi-structured interviews, expert opinion, focus groups or a combination of the tools. Furthermore, it appears that project managers in the study area do not favour such methods as the use of questionnaires, Delphi method and public hearing extensively to identify stakeholders in their projects, whereas using these methods could grant them a wider coverage for identification. This explains why SI on private corporate building projects is oftentimes not extensive and exhaustive because the methods used are often limited in coverage. Consequently, important stakeholders are sometimes omitted by the design team. The impact of such omission on project performance is often enormous in terms of completion time and completion cost (Olatunde and Alao, 2017). The non-use of the questionnaire method, Delphi method and public hearing by project managers in the study area is in contrast to Awakul and Ogunlana' (2002) study which found that identification of stakeholders and their interests are usually conducted through deskwork and a questionnaire. The $84.62 \%$ agreement in the opinion of the project managers on SI methods used in the study area implied that the near unanimity in the opinion of project manager is the true state of affair most especially as the methods where they statistically differ are not the prominent ones.

\section{Conclusion}

The study appraised the methods used for SI on building projects procured by private corporate organisations in Southwest Nigeria and concluded that the top three SI methods used in the study area are brainstorming in group meetings, interviews with experts and identification by other stakeholders. The study further concluded that the methods used for SI in the study area are not robust enough to engender extensive and exhaustive SI, since methods such as public hearing, the snowballing method, Delphi method, the use of questionnaire and self-selection in response to an advertisement are rarely used for stakeholder identification; hence, there is a chance of omission of important stakeholders which could result in poor project performance. The study also concluded that project managers, irrespective of the procurement methods employed in their projects were mostly unanimous in their choice of SI methods. Based on this conclusion, the study recommended that project managers should adopt the use of more robust and extensive SI methods such as the use of the Delphi method, public hearing, and self-selection in response to an advertisement or announcement, as this will engender a wider and exhaustive SI, thereby enhancing project performance. It was also recommended that project managers should always set aside substantial resources to be expended on SI issues, as this will help to reduce poor project performance related to the influence of stakeholders on construction projects. The main limitation for this study lies in the fact that data collection was limited to building projects procured by private corporate organisations and the adaptability of the findings to public projects may be limited, as private corporate organisations and public organisations have different characteristics. Another limitation lies in the fact that geographical location and advancement in project management behaviour in developed economies may be different from the developing economy; hence, the applicability of the findings in developed countries should be with caution. Further studies could be instituted to unravel methods used in other processes of stakeholder management, as the result of each research could be informative to enhance 
project delivery. Also, a similar study can investigate methods used in SI of public engineering projects.

\section{References}

Aaltonen, K. (2010), Stakeholder Management in International Projects, Ph.D. Thesis, Aalto University, Espoo.

Aaltonen, K. (2011), "Project stakeholder analysis as an environmental interpretation process", International Journal of Project Management, Vol. 29, pp. 165-183.

Aaltonen, K., Kujala, J. and Oijala, T. (2008), "Stakeholder salience in global projects", International Journal of Project Management, Vol. 26 No. 5, pp. 509-516.

Aapaoja, A. and Haapasalo, H. (2014), "A framework for stakeholder identification and classification in construction projects", Open Journal of Business and Management, Vol. 2, pp. 43-55.

Agri, E.M., Mailafia, D. and Umejiaku, R.I. (2017), "Impact of economic recession on macroeconomic stability and sustainable development in Nigeria", Science Journal of Economics, Vol. 2017, pp. 1-12, doi: 10.7237/sje/130.

Awakul, P. and Ogunlana, S.O. (2002), "The effect of attitudinal differences on interface conflict on large construction projects: the case of the Park Mun Dam project", Environmental Impact Assessment Review, Vol. 22 No. 4, pp. 311-335.

Bourne, L. (2009), Stakeholder Relationship Management: A Maturity for Organisational Implementation, Gower, Farnham Survey, Oxford.

Bourne, L. and Walker, D.H.T. (2006), "Visualizing stakeholder influence - two Australian examples", Project Management Journal, Vol. 37 No. 1, pp. 5-22.

Buertey, J.I.T., Amofa, D. and Atsrim, F. (2016), "Stakeholder management on construction projects: a key indicator for project success", American Journal of Civil Engineering, Vol. 4 No. 4, pp. 117-126, doi: 10.11648/j.ajce.20160404.11.

Chevalier, J.M. and Buckles, D.J. (2008), A Guide to Collaborative Inquiry and Social Engagement, Sage Publications, London.

Clarkson, M.B.E. (1995), “A stakeholder framework for analyzing and evaluating corporate social performance", Academy of Management Review, Vol. 20 No. 1, pp. 92-117.

DeVellis, R.F. (2003), Scale Development: Theory and Applications, 2nd ed., Sage, Thousand Oaks, CA.

Dietrich, P., Eskerod, P., Dalcher, D. and Sandhawalia, B. (2010), "The dynamics of collaboration in multipartner projects", Project Management Journal, Vol. 41 No. 4, pp. 59-78, doi: 10.1002/ pmj.20194.

Doyle, P. and Stern, P. (2006), Marketing Management and Strategy, Essex, 4th ed., Pearson Education Limited, Harlow.

Eyiah-Botwe, E. (2015), "An evaluation of stakeholder management role in getfund polytechnic projects delivery in Ghana”, Journal of Civil and Environmental Research, Vol. 7 No. 3, pp. 843-854.

Feige, A., Wallbaum, H. and Krank, S. (2011), "Harnessing stakeholder motivation: towards a Swiss sustainable building sector”, Building Research and Information, Vol. 39 No. 5, pp. 504-517.

Freeman, E. (1984), Strategic Management: A Stakeholder Approach, Pitman, Boston, MA.

Friedman, A.L. and Miles, S. (2006), Stakeholders: Theory and Practice, Oxford University Press, Oxford.

Gil-Lafuente, A.M. and Paula, L.B. (2013), "Algorithm applied in the identification of stakeholders", Kybernetes, Vol. 42 No. 5, pp. 674-685.

Giordano, R., Passarella, G., Uricchio, G.F. and Vurro, M. (2007), "Integrating conflict analysis and consensus reaching in a decision support system for water resource management", Journal of Environmental Management, Vol. 84, pp. 213-228.
Identifying stakeholders 
FEBE 1,2

Hornby, A.S. (2014), Oxford Advanced Learners' Dictionary of Current English, Oxford University Press, Oxford.

Jepsen, A.L. and Eskerod, P. (2009), "Stakeholder analysis in projects: challenges in using current guidelines in the real world", International Journal of Project Management, Vol. 27, pp. 335-343.

Karlsen, J.T. (2002), "Project stakeholder management", Engineering Management Journal, Vol. 14 No. 4, pp. 19-24.

Lock, D. (2007), Project Management, 9th ed., Gower, Burlington, VT.

Lynch, R. (2006), Corporate Strategy, 4th ed., Pearson Education Limited, Harlow.

Macau Daily Times (2011), Pearl River Delta Bridge Work Begins, Macau Daily Times (MDT), Macao, December 15th, p. 18.

McElroy, B. and Mills, C. (2003), "Managing stakeholders", in Turner, R.J. (Ed.), People in Project Management, Gower, Aldershot.

Mitchell, R.K., Agle, B.R. and Wood, D.J. (1997), "Toward a theory of stakeholder identification and salience: defining the principle of who and what really counts”, Academy of Management Review, Vol. 22 No. 4, pp. 853-866.

Mok, K.Y., Shen, G.Q. and Yang, J. (2015), "Stakeholder management studies in mega construction projects: a review and future directions", International Journal of Project Management, Vol. 33, pp. $446-457$.

Oke, A.E. and Ogunsemi, D.R. (2009), "Competences of quantity surveyors as value managers in a developing economy", The construction and Building Research Conferences of the Royal Institution of Chattered Surveyor, 10-11 September, pp. 23-38.

Olander, S. and Landin, A. (2008), "A comparative study of factors affecting the external stakeholder management process", Construction Management and Economics, Vol. 26 No. 6, pp. 553-562.

Olatunde, N.A. (2019), Assessment of Stakeholder Management in Construction Projects Procured by Private Corporate Organisations in Southwestern Nigeria, $\mathrm{PhD}$ thesis in Quantity Surveying of Obafemi Awolowo University, Ile-ife.

Olatunde, N.A. and Alao, O. (2017), "Quantitative appraisal of cost and time performance of construction projects in public and private universities in Osun State, Nigeria", Journal of Engineering, Design and Technology, Vol. 15 No. 5, pp. 619-634.

Olatunde, N.A. and Odeyinka, H.A. (2021a), "Extent of stakeholder management practices in building projects procured by private corporate organisations in Nigeria", Built Environment Project and Asset Management, in press, available at: www.emerald insight/bepam (accessed 8 June 2021).

Olatunde and Odeyinka (2021b), "Factors influencing stakeholder management in building projects procured by private corporate organisations", Journal of Engineering Projects and Production Management, Vol. 11 No. 1, pp. 9-18.

Project Management Institute (2013), A Guide to the Project Management Book of Knowledge (PMBOK), 5th ed., Project Management Institute, Newtown Square, PA.

Reed, M.S., Graves, A., Dandy, N., Posthumus, H., Hubacek, K., Morris, J., Prell, C., Quinn, C.H. and Stringer, L.C. (2009), "Who's in and why? A typology of stakeholder analysis methods for natural resource management", Journal of Environmental Management, Vol. 90, pp. 1933-1949.

Smith, J. and Love, P.E.D. (2004), "Stakeholder management during project inception: strategic needs analysis", Journal of Architectural Engineering, Vol. 10 No. 1, pp. 22-33.

Von, J.F.J. and Achterkamp, M.C. (2006), "Stakeholder identification in innovation projects going beyond classification", European Journal of Innovation Management, Vol. 9 No. 2, pp. 161-178.

Yang, J.R. and Shen, Q.G. (2015), "Framework for stakeholder management in construction projects", Journal of Management in Engineering, Vol. 31 No. 4, pp. 4251-4261. 
Yang, J., Shen, Q. and Ho, M. (2009), “An overview of previous studies in stakeholder management and its implications for the construction industry", Journal of Facilities Management, Vol. 7 No. 2, pp. 159-175.

Identifying stakeholders

Yang, J., Shen, Q.G., Ho, M., Drew, D.S. and Xue, X. (2011), "Stakeholder management in construction: an empirical study to address research gaps in previous studies", International Journal of Project Management, Vol. 29, pp. 900-910.

\section{Further reading}

Briner, W., Hastings, C. and Geddes, M. (1996), Project Leadership, Gower, Aldershot.

\section{Corresponding author}

Nathaniel Ayinde Olatunde can be contacted at: nathaniel.olatunde@uniben.edu

For instructions on how to order reprints of this article, please visit our website:

www.emeraldgrouppublishing.com/licensing/reprints.htm

Or contact us for further details: permissions@emeraldinsight.com 